\title{
Holospora (ex Hafkine 1890) nom. rev., a Genus of Bacteria Inhabiting the Nuclei of Paramecia
}

\author{
B. V. GROMOV AND D. V. OSSIPOV \\ Biological Institute, Leningrad University, Stary Peterhof, Leningrad 198904, \\ Union of Soviet Socialist Republic
}

The genus Holospora was named and described by Hafkine in 1890 for bacteria which inhabit the nuclei of paramecia. Because holosporas could not be cultivated, the name Holospora and the names of the species in the genus were not included in the Approved Lists of Bacterial Names (Skerman et al., ed., Int. J. Syst. Bacteriol. 30:225-420, 1980). Recently, we examined organisms identified as belonging to two Holospora species, "Holospora undulata" Hafkine 1890 and "Holospora obtusa" Hafkine 1890 and confirmed the descriptions of Hafkine. In the past, some workers have considered these organisms to be hereditary factors or particles, referred to as omega and iota particles. This practice should be abandoned, and the organisms should be referred to by their proper scientific names. Consequently, the names Holospora, $H$. undulata (the type species), and $H$. obtusa are revived here for the same organisms to which the names were originally applied by Hafkine. Because these organisms have not been cultivated, the illustrations and descriptions of these organisms serve as representatives of their nomenclatural types.

Symbiosis between bacteria and ciliates is common $(1,19)$. Early microbiologists observed several types of bacteria that inhabited paramecia, and in 1890 Hafkine (8) gave a review of the forms described to that date. In the same paper, Hafkine named and described a new genus, "Holospora" (names in quotation marks are not on the Approved Lists of Bacterial Names [22] and have not been validly published since 1 January 1980), and three new species of unusual bacteria, which had complex life cycles and developed in the nuclei of paramecia. Hafkine believed that the host of these bacteria was Paramecium aurelia, but it is evident from his illustrations that the host was Paramecium caudatum. However, the interest of bacteriologists in these ciliate symbionts was very ephemeral, and the previously published data on these organisms currently are generally considered to be questionable. Bergey's Manual of Determinative Bacteriology, 8th ed. (2) does not mention any species of protozoan symbionts. On the other hand, in the 1940s (especially when the work of Sonneborn [24] appeared), the intracellular symbionts of paramecia commonly were the objects of protozoological and genetic studies, although they were considered to be some kind of cytoplasmic hereditary factors or particles and hence were designated by Greek letters, a practice which has persisted until now (13, 24, 25; D. V. Ossipov, B. V. Gromov, K. A. Mamkaeva, I. I. Skoblo, O. N. Borchsenius, M.
S. Rautian, S. A. Podlipaev, and S. I. Fokin, Abstr. 5th Int. Congr. Protozool., p. 442, 1977). The bacterial nature of these particles has been recognized, but it was only in 1974 that Preer and co-workers (19) proposed scientific names for the symbionts of $P$. aurelia and worked out the systematics of these organisms. However, these authors did not consider the genus " $\mathrm{Ho}$ lospora" or other forms specific for P. caudatum.

In 1929, a bacterium similar to "Holospora obtusa" Hafkine was examined by Fiveiskaja (4); her description of this organism was in good agreement with the description of Hafkine. We are unaware of any other mention of "Holospora" from 1929 until 1972, at which time an organism similar in all respects to "Holospora undulata" was examined and described by Ossipov and Ivakhnjuk (14), who referred to the cells of this organism as omega particles. Later " $H$. obtusa" was described by Ossipov and coworkers $(17,18)$ under the designation iota particles.

The morphologies, ultrastructures, and biological patterns of two "Holospora" species have been described in numerous publications $(5,7$, 10-18, 20, 21, 23; Ossipov et al., Abstr. 5th Int. Congr. Porotzool., p. 442, 1977; D. V. Ossipov, I. S. Ivakhnjuck, I. I. Skoblo, and M. S. Rautian, Abstr. 4th Int. Congr. Protozool., p. 307, 1973). These recent data, which were obtained with modern techniques, are in a good or even excel- 
lent agreement with the original descriptions and interpretations of Hafkine.

" $H$. undulata" and "H. obtusa" are obligate intranuclear symbionts, and all attempts to cultivate these organisms in artificial media have failed (13). These symbionts are highly specific for clones of $P$. caudatum; " $H$. undulata" develops only in micronuclei, and " $H$. obtusa" develops only in macronuclei $(10,11,13-15)$. Furthermore, these organisms are infective, for pure cells of $P$. caudatum obtain bacteria if they are grown in a medium together with infected cells.

These bacteria are gram negative. In their life cycles, there is an alternation of two morphological stages. The vegetative form of " $H$. undulata" is spindle shaped (length, 1.5 to $2.0 \mu \mathrm{m}$ ) and multiplies by transverse fission (Fig. 1A and B). The " $H$. obtusa" vegetative form is rod shaped (Fig. 1D and F). The other form is a spiral (length, about $12 \mu \mathrm{m}$ ) in " $H$. undulata" and an elongated rod (length, about $18 \mu \mathrm{m}$ ) in " $H$. obtusa." The elongated cells originate from the vegetative cells, and intermediate forms are usually present in infected nuclei. The elongated cells do not divide; they represent the infective stage. They are thought to be specialized spores (4-8, 10-18; Ossipov et al., Abstr. 5th Int. Congr. Protozool., p. 442, 1977; Ossipov et al., Abstr. 4th Int. Congr. Protozool., p. 307, 1973). The ultrastructure of the vegetative cells is similar to that of typical gram-negative bacteria $(5,6,12)$. The infectious cells (Fig. 1G and Fig. 2) consist of two parts; one part is a homogenous area representing the hyperdeveloped periplasm, and the other part is the membrane system and cytoplasm $(5,6)$. The cytoplasm is basophilic, but the other part of the cell does not absorb dye (Fig. 1E).

During each division of an infected Paramecium cell, some of the infectious cells remain outside the daughter nuclei; these cells are later excreted into the medium.

Direct evidence for spore infectivity has been obtained for " $H$. obtusa" (15) and " $H$. undulata" (21). The short, vegetative cells have been shown to be noninfective $(15,21)$.

The infection of bacterium-free ciliates by infectious cells of " $H$. obtusa" has been examined by Ossipov and Podlipaev (15). A cell is taken up into the food vacuole by phagocytosis, but instead of being digested, it penetrates the host cytoplasm, where a complex consisting of four or five layers of paired membranes is formed around the symbiont. A vegetative cell is then liberated from the spore, a process which can be induced artificially by a low $\mathrm{pH}(7)$. The vegetative cell moves from the food vacuole into the nucleus by means of directional transport involving serial replacement of the host membrane systems surrounding the symbiont at all stages of its penetration. The total process of symbiont penetration takes about $1 \mathrm{~h}$. The presence of symbionts in the nuclei usually has no effect on the dividing capacity of the cells, although it prevents sexual reorganization and conjugation and has an obvious effect on nuclear morphology and structure $(5,12,13,16,18,20$; Ossipov et al., Abstr. 4th Int. Congr. Protozool., p. 307, 1973). Infected nuclei can be cleared of symbionts spontaneously or artificially.

In all recent publications dealing with holosporas, these organisms are referred to as omega or iota particles, although similarity of the particles to holosporas is mentioned occasionally (13, 18; Ossipov et al., Abstr. 5th Int. Congr. Protozool., p. 442, 1977). Nevertheless, the identity of these organisms as members of the " $\mathrm{Ho}$ lospora" species described by Hafkine is obvious from a comparison of the pictures of Hafkine (Fig. 1A and D) with the recent photographs obtained by phase-contrast microscopy and electron microscopy. The observations of Hafkine have been confirmed and supplemented by recent investigators, and these symbionts have now been examined better than some named bacteria which have definite positions in bacterial classification.

Because the holosporas cannot be cultivated at this time, the names Holospora, $H$. undulata, and $H$. obtusa were not included in the recently published Approved Lists of Bacterial Names (22). However, according to Rule 18a of the International Code of Nomenclature of Bacteria (9), "for a species which has not so far been maintained in laboratory culture or for which a type strain does not exist, a description, preserved specimen, or an illustration (see also Rule $18 \mathrm{~h}$ ) may serve as the type." Hafkine (8) gave sufficiently precise and detailed descriptions of the holosporas which he named, and in the absence of pure cultures of his organisms, his descriptions and illustrations can and should serve as the types until these organisms can be cultivated. Therefore, the names Holospora, $H$. undulata, and $H$. obtusa are here revived for the same taxa to which Hafkine originally applied these names. The third species of Hafkine, "Holospora elegans," has not been reported since Hafkine observed it, and thus it is not considered here.

The following amended descriptions of the genus Holospora and the species $H$. undulata and $H$. obtusa are in accord both with the original observations of Hafkine and with recent data. 


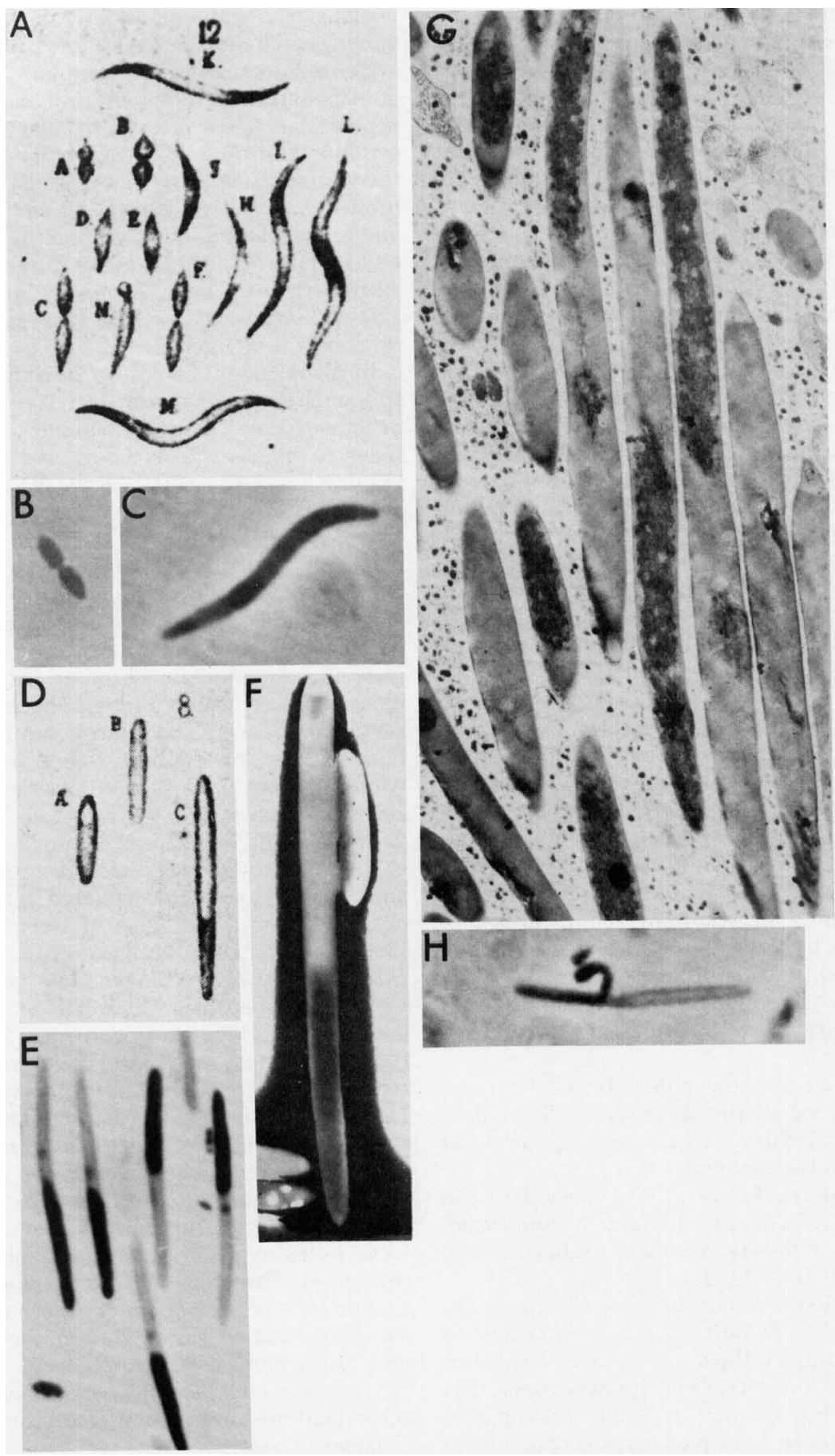

Fig. 1. Morphology of Holospora cells. (A) H. undulata, from Hafkine (8). (B and C) H. undulata dividing vegetative cells and spore. Phase-contrast microscopy, X2,000. From Ossipov et al. (13). (D) H. obtusa, from Hafkine (8). (E) Infectious cells of $H$. obtusa stained with methylene blue. $\times 2,000$. From Gromov et al. (7). (F) Negatively stained infectious cell and vegetative cell (right) of $H$. obtusa. Electron microscopy, $\times 6,000$. From Gromov et al. (7). (G) Thin sections of H. obtusa infectious cells. $\times 10,000$. From Ossipov et al. (13). (H) Reaction of an $\mathrm{H}$. obtusa infectious cell to an acid environment. Phase-contrast microscopy, $\times 2,000$. From Gromov et al. (7). 


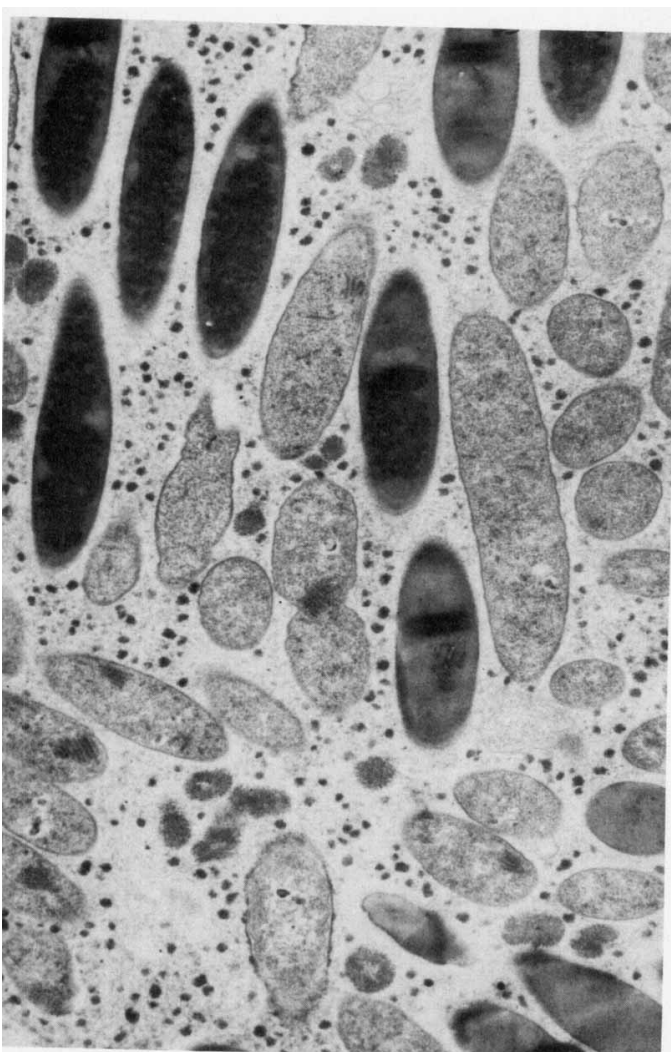

FIG. 2. Thin section of a P. caudatum macronucleus infected with $H$. obtusa. Both vegetative cells and infectious cells (electron dense) are visible. $\times 16,000$. From Gromov et al. (6).

Genus Holospora (ex Hafkine 1890) nom. rev., emend. (Ho.lo'spo.ra. Gr. adj. holos whole, complete; Gr. noun sporus seed; M.L. noun spora spore; M.L. fem. noun Holospora whole spore.)

Members of this genus are obligately intracellular ciliate symbionts with a life cycle which includes two alternative stages, a vegetative stage and an infectious stage. Vegetative forms are short, straight, spindle-shaped rods, which are 1 to $3 \mu \mathrm{m}$ long; the ends of the rods may be rounded. The cell diameter varies from 0.5 to 1.0 $\mu \mathrm{m}$. The rods divide by transverse fission; they are not infectious. Infectious cells (spores) are several times longer than vegetative cells, and spores are produced when vegetative cells grow without division. Infectious cells consist of two parts, a homogeneous area and a cytoplasmmembrane area. Pure culture growth in vitro has not been possible.

The cells are gram negative, nonmotile, and not flexible.

The type species is $H$. undulata.
Holospora undulata (ex Hafkine 1890) nom. rev., emend. (un.du.la'ta. L. adj. undulatus undulated, with waves.)

Cells develop in the micronuclei of $P$. caudatum. Vegetative cells are spindle shaped and are up to $3 \mu \mathrm{m}$ long. Infectious cells are sinuous filaments about $16 \mu \mathrm{m}$ long and have tapered ends.

The type is the original description and illustration of Hafkine (8).

Clone M1-48 of $P$. caudatum containing $H$. undulata in its micronuclei has been deposited in the culture collection of the Laboratory of Invertebrate Zoology, Biological Research Institute, Leningrad University.

Holospora obtusa (ex Hafkine 1890) nom. rev., emend. (ob.tu'sa. L. adj. obtusus obtuse.)

Cells develop in the macronuclei of $P$. caudatum. The vegetative rods have rounded ends and are about $3 \mu \mathrm{m}$ long. The infectious cells are elongated and straight and are about $18 \mu \mathrm{m}$ long.

The type is the original description and illustration of Hafkine (8).

Clone M-115 of $P$. caudatum containing $H$. obtusa in its macronuclei has been deposited in the culture collection of the Laboratory of Invertebrate Zoology, Biological Research Institute, Leningrad University.

The systematics of the bacterial symbionts of $P$. aurelia have been described by Preer et al. (19). Most of the known species were placed in a new family, "Caedobacteriaceae" Preer et al. 1974 (not on the Approved Lists of Bacterial Names [22] and not validly published since 1 January 1980; hence, without standing in nomenclature). Holospora differs in many respects from the members of the family "Caedobacter. iaceae," which are intracytoplasmic symbionts that do not have specialized life cycles.

The most important characteristics of the holosporas are their obligately symbiotic nature and their unique life cycles. As obligately intracellular symbionts, holosporas should be considered members of the order Rickettsiales. Some bacteria belonging to the Rickettsiales have life cycles with both vegetative and infectious forms, and in some bacteria these forms have different shapes and sizes and different ultrastructural patterns (e.g., Rickettsiella [3]). At present, it seems premature to assign the genus Holospora to the Rickettsiales. The taxonomic position of this genus must await the results of further studies on these organisms.

\section{REPRINT REQUESTS}

Address reprint requests to: Boris V. Gromov, Biological Institute, Leningrad University, Oranienbaumskoye sch. 2, Stary Peterhof, Leningrad 198904, USSR. 


\section{LITERATURE CITED}

1. Ball, G. H. 1969. Organisms living on and in protozoa, p. 565-718. In T. T. Chen (ed.), Research in protozoology, vol. 3. Pergamon Press, New York.

2. Buchanan, R. E., and N. E. Gibbons (ed.). 1974. Bergey's manual of determinative bacteriology, 8 th ed. The Williams \& Wilkins Co., Baltimore.

3. Devauchelle, G., G. Meynadier, and C. Vago. 1972. Etude ultrastructurale du cycle de multiplication de Rickettsiella melolonthae (Krieg), Philip, dans les hemocytes de son hote. J. Ultrastruct. Res. 38:134-148.

4. Fiveiskaja, A. 1929. Einfluss der Kernparasiten der Infusorien auf den Stoffwechsel. Arch. Protistenkd. 65: $275-298$.

5. Gromov, B. V., K. A. Mamkaeva, and D. V. Ossipov. 1975. Characteristics of cytodifferentiation of omegaparticles-symbiotic bacteria from the micronucleus of Paramecium caudatum clone M1-48. Microbiology (USSR) 44:97-102.

6. Gromov, B. V., K. A. Mamkaeva, and D. V. Ossipov. 1976. Ultrastructure of the I-particles-symbiotic bacteria of the macronucleus of Paramecium caudatum (Protozoa, Ciliata). Izv. Akad. Nauk SSSR Ser. Biol. 3: 399-409.

7. Gromov, B. V., D. V. Ossipov, and K. A. Mamkaeva. 1974. Peculiarity in the reaction on extremal $\mathrm{pH}$ values of elongated cells-spores of macronuclear symbiotic bacteria of Paramecium caudatum. Dokl. Akad. Nauk SSSR. 217:712-714.

8. Hafkine, W. M. 1980. Maladies infectieuses des paramecies. Ann. Inst. Pasteur Paris 4:148-162.

9. Lapage, S. P., P. H. A. Sneath, E. F. Lessel, V. B. D. Skerman, H. P. R. Seeliger, and W. A. Clark (ed.). 1975. International code of nomenclature of bacteria, 1976 revision. American Society for Microbiology, Washington, D.C.

10. Ossipov, D. V. 1973. Specific infectious specificity of the omega-particles, micronuclear symbiotic bacteria of Paramecium caudatum. Cytologia 15:211-216.

11. Ossipov, D. V. 1975. The specificity of localization of omega particles, the intranuclear symbiotic bacteria in Paramecium caudatum. Acta Protozool. 14:43-57.

12. Ossipov, D. V., B. V. Gromov, and K. A. Mamkaeva. 1973. Electron microscope examination of omega-particles (bacterial symbionts of the micronucleus) and nuclear apparatus of Paramecium caudatum clone M1-
48. Cytologia 15:97-103.

13. Ossipov, D. V., B. V. Gromov, K. A. Mamkaeva, M. S. Rautian, I. I. Skoblo, and $O$. N. Borchsenius. 1976. The use of symbiotic bacteria for analysis of the structure and function of nuclear apparatus of ciliates. Protozoologia (USSR) 1:101-139.

14. Ossipov, D. V., and I. S. Ivakhnyuk. 1972. Omegaparticles--micronuclear symbiotic bacteria of Parame. cium caudatum clone M1-48. Cytologia 14:1414-1419.

15. Ossipov, D. V., and S. A. Podlipaev. 1977. Electron microscope examination of early stages of infection of Paramecium caudatum by bacterial symbionts of the macronucleus (iota-bacteria). Acta Protozool. 16:289308.

16. Ossipov, D. V., M. S. Rautian, and I. I. Skoblo. 1974. The loss of the ability for sexual process in cells of Paramecium caudatum infected with endonuclear symbiotic bacteria. Genetica (USSR) 10:62-70.

17. Ossipov, D. V., I. I. Skoblo, and M. S. Rautian. 1975. Macronuclear symbiotic bacteria of ciliate Paramecium caudatum. Cytologia 17:95-97.

18. Ossipov, D. V., I. I. Skoblo, and M. S. Rautian. 1975. Iota-particles, macronuclear symbiotic bacteria of ciliate Paramecium caudatum clone M115. Acta Protozool. 14:263-280.

19. Preer, J. R., L. B. Preer, and A. Jurand. 1974. Kappa and other endosymbionts in Paramecium aurelia. Bacteriol. Rev. 38:113-163.

20. Rautian, M. S., D. V. Ossipov, and I. I. Skoblo. 1975. The change of chromatin in the micronucleus of Paramecium caudatum (Ciliata) when infected with omegaparticles. Cytologia 17:1200-1207.

21. Rautian, M. S., I. I. Skoblo, and D. V. Ossipov. 1978. The infective stage in the life cycle of micronuclear symbiotic bacteria of Paramecium caudatum and concentrational effect of infection. Cytologia 20:455-459.

22. Skerman, V. B. D., V. McGowan, and P. H. A. Sneath (ed.). 1980. Approved lists of bacterial names. Int. J. Syst. Bacteriol. 30:225-420.

23. Skoblo, I. I., M. S. Rautian, and D. V. Ossipov. 1978. The loss of the generative nuclei in Paramecium caudatum during early stages of infection by symbiotic bacteria. Acta Protozool. 17:321-330.

24. Sonneborn, T. M. 1947. Recent advances in the genetics of Paramecium and Euplotes. Adv. Genet. 1:263-358.

25. Sonneborn, T. M. 1959. Kappa and related particles in Paramecium. Adv. Virus Res. 6:229-356. 